\title{
Treating postmenopausal osteoporosis in women at increased risk of fracture - critical appraisal of bazedoxifene: a review
}

This article was published in the following Dove Press journal:

International Journal of Women's Health

17 August 2009

Number of times this article has been viewed

\author{
Peter Vestergaard \\ Susanna vid Streym Thomsen \\ Department of Endocrinology \\ and Metabolism C, Aarhus University \\ Hospital, Aarhus, Denmark
}

\begin{abstract}
Several categories of drugs to treat osteoporosis exist in the form of bisphosphonates, strontium, parathyroid hormone, and selective estrogen receptor modulators (SERM). Advantages and disadvantages exist for each category as some patients may, for example, not tolerate bisphosphonates for gastrointestinal side effects, and especially in women in whom osteoporosis is frequent, several options for treatment are needed. The objectives of this review were to critically appraise the effects of bazedoxifene on risk of fractures especially in women at high risk of fractures. A systematic literature search was conducted for studies, especially randomized controlled trials with fractures as end-points. Bazedoxifene is a new member of the SERM group. The literature search identified one randomized controlled trial with fractures as end-point. This was a 3-year randomized double-blind placebo controlled trial in which 7492 postmenopausal women aged 55 to 85 years were randomly allocated to 1) bazedoxifene (20 [n=1886] or $40[\mathrm{n}=1872] \mathrm{mg} /$ day $) ; 2)$ raloxifene (60 mg/day, $\mathrm{n}=1849)$; or 3$)$ placebo $(n=1885)$. The risk of vertebral fractures decreased with both 20 (HR $0.58,95 \%$ CI 0.38 to 0.89 ) and 40 (HR $0.63,95 \%$ CI 0.42 to 0.96 ) $\mathrm{mg}$ of bazedoxifene per day compared to placebo. There was no reduction in non-vertebral fractures. A subgroup of women with a priori high risk of fractures was identified post hoc. In this subgroup there was a reduction in the risk of non-vertebral fractures with the $20 \mathrm{mg}$ dose of bazedoxifene compared to placebo (HR $0.50,95 \%$ CI 0.28 to 0.90 ). In the $40 \mathrm{mg}$ bazedoxifene group no significant reduction in non-vertebral fractures was seen in this subgroup (HR 0.70, 95\% CI 0.40 to 1.20 ). In general post-hoc defined subgroup analyses should be interpreted with caution. However, the results indicate that bazedoxifene may be effective in preventing vertebral fractures in postmenopausal women with osteoporosis.
\end{abstract}

Keywords: bazedoxifene, fracture, bone mineral density

\section{Introduction}

Several categories of drugs to treat osteoporosis exist in the form of bisphosphonates, strontium, parathyroid hormone, and selective estrogen receptor modulators (SERM). Advantages and disadvantages exist for each group as some patients may, for example, not tolerate bisphosphonates for gastrointestinal side effects, and especially in women in whom osteoporosis is frequent, several options for treatment are needed. This is particularly important because of the involvement of estrogen deficiency in the pathogenesis of osteoporosis in women. The objectives of this review were to critically appraise the effects of bazedoxifene on risk of fractures especially in women at high risk of fractures. A systematic search of the literature was conducted for studies, especially randomized controlled trials with fractures as end-points. 
The paper evaluates the effects of estrogen and the effects of SERM on estrogen, and the pharmacokinetics and pharmacodynamics of bazedoxifene and its effects on clinical end-points, especially fractures but also other important end-points linked to the estrogen system such as breast cancer and endometrial cancer. The literature was searched systematically and the effects of bazedoxifene were critically appraised and compared to the effects of other drugs not just in the SERM class of drugs but also with other classes of drugs against osteoporosis. The paper thus summarizes not just the effects from randomized controlled trials of bazedoxifene, but also assesses its effect in comparison with other drug classes. It also assesses the effects on bone mineral density in relation to the effects on fracture risk.

Bazedoxifene is a third-generation SERM. ${ }^{1}$ Tamoxifen was the first-generation, and raloxifene the second. Significant differences have been shown between the generations in terms of effects especially on the uterus and the breast tissue. ${ }^{2}$ The SERM class of drugs are drugs with selective effects on the estrogen receptor. In contrast to estrogens and estrogen receptor agonists, these are partial agonists/ antagonists. Development of newer generations with more selective effects may thus prove advantageous in terms of effects on bone and side effects.

\section{Estrogen effects}

Estrogens have positive effects on bone by inhibiting osteoclastic resorption, ${ }^{3,4}$ which leads to an increase in bone mineral density (BMD) ${ }^{5}$ and a decrease in the risk of fractures..$^{6-8}$ In a meta-analysis, estrogen therapy in any form was associated with a decrease in the risk of non-vertebral fractures (relative risk [RR] 0.73, 95\% confidence internval [CI] 0.56 to 0.94$)^{9}$ and vertebral fractures (RR $0.67,95 \%$ CI 0.45 to 0.98$).{ }^{10} \mathrm{~A}$ subsequent large-scale randomized controlled trial ${ }^{6}$ has shown that estrogen plus progestogen were borderline significantly effective in preventing hip (hazard ratio [HR] $0.66,95 \% \mathrm{CI} 0.45$ to 0.98 ) and vertebral fractures (HR $0.66,95 \%$ CI 0.44 to 0.98 ), although this significance was not sustained after adjustment for confounders (HR $0.66,95 \%$ CI 0.33 to 1.33 for hip fractures and HR $0.66,95 \%$ CI 0.32 for 1.34 for vertebral fractures). For conjugated estrogens alone, a large-scale randomized controlled trial also showed a reduction in hip (HR 0.61, 95\% CI 0.41 to 0.91 ) and vertebral fractures (RR 0.62, 95\% CI 0.42 to 0.93 ), but again this not sustained after adjustment for confounders (HR 0.61, 95\% CI 0.33 to 1.11 for hip fractures, and HR $0.62,95 \%$ CI 0.34 to 1.13 for vertebral fractures). ${ }^{8}$
However, estrogen and estrogen plus progestogens (estrogen therapy: ET or estrogen plus progestogen therapy: EPT) have been associated with detrimental effects in other organ systems. In the breast, EPT has been associated with an increased risk of breast cancer, ${ }^{6}$ whereas ET has not been associated with an increased risk of breast cancer. ${ }^{8}$ For cardiovascular events, EPT has been associated with an increased risk of myocardial infarction and other cardiac events and an increased risk of cerebrovascular events. ${ }^{6}$ ET has been associated with an increased risk of stroke, but not cardiac events. ${ }^{8}$ ET is associated with an increased risk of endometrial cancer, ${ }^{11}$ but EPT has not. ${ }^{12}$ Another concern with ET and EPT is an increased risk of deep venous thromboembolism. ${ }^{12}$ Some of the differences between ET and EPT may be linked to the progestogen component of EPT, as the progestogens may possess androgen effects.

The studies mentioned above have mainly been for conjugated estrogens; however similar results have been reported for the native 17-beta-estradiol. ${ }^{13,14}$

\section{The estrogen receptor}

The estrogen receptor per se contains two subgroups: estrogen receptor alpha is located in the breast and endometrium, whereas estrogen receptor beta is located in bone, heart, endothelium and a number of other tissues. ${ }^{15}$ Selective actions against subtypes of the estrogen receptor may thus modulate some of the detrimental effects of estrogen and enhance the positive effects.

\section{SERM}

These are drugs with specific actions on subtypes of the estrogen receptor. They are typically agonist/antagonists of the estrogen receptor.

The first clinically used drug in the class was tamoxifene, which is in use as a drug to treat estrogen receptor positive breast cancer. However, tamoxifene suffers some of the same detrimental effects as estrogen such as endometrial cancer. ${ }^{16}$ Tamoxifene does not seem to prevent fractures in women with breast cancer ${ }^{17}$ although BMD may increase. ${ }^{18-20}$

Raloxifene was marketed as a drug to treat and prevent osteoporosis. It was shown to increase $\mathrm{BMD}^{21}$ and to reduce the risk of vertebral fractures, ${ }^{22-26}$ although the risk of non-vertebral fractures did not seem to decrease. ${ }^{27}$ Raloxifene was associated with a significant decrease in the risk of breast cancer (estrogen receptor positive breast cancer) ${ }^{28,29}$ It was associated with an increased risk of deep venous thromboembolism ${ }^{22}$ and an increased risk of leg cramps. ${ }^{22}$ In older women an increased risk of fatal ${ }^{30}$ but not 
non-fatal strokes has been reported. Raloxifene does not seem to significantly affect the rate of cardiovascular events ${ }^{30,31}$ although serum cholesterol levels may decrease. ${ }^{21}$ Raloxifene is associated with an increased risk of vasomotor symptoms such as hot flushes. ${ }^{22}$ Raloxifene does not seem to stimulate the endometrium ${ }^{21}$ although more episodes of endometrial cavity fluid have been reported. ${ }^{22}$

Other SERMs include lasofofoxifene, ${ }^{32,33}$ toremifene, idoxifene, arzoxifene, acolbifene and bazedoxifene along with a number of other compounds. ${ }^{34}$ For most of these only few clinical data are available.

\section{Fracture risk}

The major determinants of fracture risk are age and gender. ${ }^{35}$ Other major determinants include reduced bone mineral density, ${ }^{36}$ prior fractures, ${ }^{37}$ corticosteroid use,${ }^{38,39}$ smoking, ${ }^{40,41}$ alcohol intake, ${ }^{42}$ and a number of other factors such as low body weight, ${ }^{43}$ reduced eye sight, ${ }^{44}$ reduced physical performance, ${ }^{44}$ and use of psychotropic drugs. ${ }^{45-47}$

Special scores have been constructed to identify women at high risk of fractures using clinical risk factors ${ }^{48}$ in addition to low BMD. This is particularly important as it may be more difficult to show significant fracture risk reductions in randomized controlled trials in women at low risk (say, with low BMD but no prior fractures equivalent to a secondary preventive scenario) than in women at high risk of fractures (women with, say, a prior spine fracture - a tertiary preventive scenario). ${ }^{49}$

A special algorithm, the FRAX algorithm ${ }^{48}$ has been constructed to predict expected 10-year risk of fractures (hip or major osteoporotic fractures) based on age (only valid in the range 40 to 90 years), gender, weight, height, prior fracture, parental fracture history, current smoking, glucocorticoid use, rheumatoid arthritis, secondary osteoporosis, alcohol intake, and femoral neck BMD.

\section{Bazedoxifene Methods}

The effects of bazedoxifene were reviewed using a systematic search of Pubmed, Embase, and Web of Science on June 19, 2009 , using the term 'bazedoxifene'. This produced a total of 213 unique references (46 from Pubmed, 148 from Embase, and 120 from Web of Science).

\section{Pharmacokinetics}

Bazedoxifene is rapidly absorbed ${ }^{50}$ with a $t_{\max }$ of approximately 2 hours and exhibits a linear increase in plasma concentrations for single doses from $0.5 \mathrm{mg}$ up to $120 \mathrm{mg}$.
Following intravenous administration of a $3 \mathrm{mg}$ dose of bazedoxifene, the volume of distribution is $14.7 \pm 3.9 \mathrm{~L} / \mathrm{kg}$. Bazedoxifene is highly bound (95.8\% to $99.3 \%)$ to plasma proteins in vitro. Bazedoxifene is extensively metabolized in women. Glucuronidation is the major metabolic pathway. Little or no cytochrome P450-mediated metabolism is evident. Bazedoxifene-5-glucuronide is the major circulating metabolite. The concentrations of this glucuronide are approximately 10-fold higher than those of unchanged active substance in plasma. Bazedoxifene is eliminated with a half-life of approximately 30 hours. Steady-state concentrations are achieved by the second week of once-daily administration. The apparent oral clearance of bazedoxifene is approximately 4 to $5 \mathrm{~L} / \mathrm{h} / \mathrm{kg}$. The major route of excretion of radio-labeled bazedoxifene is the feces, and less than $1 \%$ of the dose is eliminated in urine. ${ }^{32}$

\section{Pharmacodynamics}

The SERMs differ significantly in terms of tissue specificity. ${ }^{51}$ Bazedoxifene seems to have less effect on the uterus than estradiol and raloxifene in animal experiments ${ }^{52}$ due to lower estrogen receptor alpha agonistic effects. ${ }^{53}$ In a study on rats $^{52}$ the uterine weight differed significantly betweem bazedoxifene $0.5 \mathrm{mg} / \mathrm{kg}$ (mean \pm SEM: $32.7 \pm 2.40,135 \%$ of control weight), raloxifene $0.5 \mathrm{mg} / \mathrm{kg}(45.0 \pm 1.23 \mathrm{mg}, 185 \%$ of control weight), and conjugated estrogens $(98.7 \pm 6.30 \mathrm{mg}$, $406 \%$ of control weight). In human studies bazedoxifene was associated with a decreased thickness of the endometrium at doses of 30 to $40 \mathrm{mg}$ /day compared to placebo or conjugated estrogen plus medroxyprogesterone (mean \pm SEM increase: $0.04 \pm 0.12 \mathrm{~mm}$ for $30 \mathrm{mg}, 0.12 \pm 0.11 \mathrm{~mm}$ for $40 \mathrm{mg}$, $0.58 \pm 0.21 \mathrm{~mm}$ for placebo, and $1.60 \pm 0.23 \mathrm{~mm}$ for conjugated estrogen plus medroxyprogesterone acetate after 168 days). ${ }^{54}$ This is in contrast to effects of other SERMs such as tamoxifen ${ }^{16}$ and raloxifene. ${ }^{22}$ In the mammary gland in animals bazedoxifene was more antagonistic to conjugated estrogens than raloxifene and lasofofoxifene. ${ }^{53}$ Bazedoxifene thus has more more tissue-specific effects than other SERMs.

\section{Effects on BMD}

In a 2-year, randomized, placebo-controlled, double-blind trial 1434 postmenopausal women ( $\geq 45$ years and $\geq 1$ year postmenopausal) were randomly allocated in a dose-dependent manner to bazedoxifene (10 [n=321], $20[\mathrm{n}=322]$ or $40 \mathrm{mg} /$ day $[\mathrm{n}=319])$, raloxifene $(60 \mathrm{mg} /$ day, $\mathrm{n}=311)$ or placebo $(\mathrm{n}=310) .{ }^{55}$ The inclusion criteria were: 1) osteopenia (lumbar spine or femoral neck T-score 
between-1 and-2.5); or 2) clinical risk factors for osteoporosis (family history of fracture, bilateral oophorectomy, current smoking, weight $<58 \mathrm{~kg}$, inadequate calcium intake, or low physical activity). ${ }^{55}$ Bazedoxifene was significantly more efficient in increasing BMD than placebo and was equally effective as raloxifene in increasing BMD. There was no significant trend with bazedoxifene dose and BMD. ${ }^{55}$ However, at 12 to 24 months bazedoxifene 20 to $40 \mathrm{mg}$ was more efficient in increasing hip BMD than 10 to $20 \mathrm{mg} .{ }^{55}$ The patients in this study on bazedoxifene and BMD were in general at low risk of fractures, ${ }^{55}$ as they were only osteopenic and had additional risk factors which did not place them at high risk of fractures.

BMD was unchanged at 24 months compared to baseline with bazedoxifene in contrast to a decline with placebo, ${ }^{55}$ in contrast to other drugs against osteoporosis, which significantly increase BMD in the range of $3 \%$ in the femoral neck and $6.5 \%$ in the lumbar spine with alendronate after 24 months. ${ }^{56}$ The difference in BMD at 24 months of around $1.5 \%$ between bazedoxifene and placebo (around $0.1 \mathrm{Z}$-scores) would translate into a fracture risk reduction of $1.5^{-0.1}=0.95$ $(5 \%)$ for overall fracture risk and $2.3^{-0.1}=0.90(10 \%)$ for spine fractures using the risk estimates of Marshall et al. ${ }^{36}$

\section{Effects on fracture risk}

In a 3-year, randomized, double-blind, placebo-controlled trial 7492 postmenopausal ( $\geq 2$ years after last menstruation) women aged 55 to 85 years were randomly allocated to 1 ) bazedoxifene $(20[\mathrm{n}=1886]$ or $40[\mathrm{n}=1872] \mathrm{mg} /$ day $), 2)$ raloxifene (60 mg/day, $n=1849)$, or 3$)$ placebo $(n=1885) .{ }^{57}$ The inclusion criteria were: 1$) \geq 1$ radiologically confirmed spine fracture ( $\geq 20 \%$ compression) and lumbar spine and femoral neck T-scores $>-4$; or 2 ) in the absence of vertebral fractures lumbar spine or femoral neck T-scores should be between -2.5 and $-4 .{ }^{57}$ Overall, around two thirds of the included patients completed the trial. ${ }^{57}$

The risk of vertebral fractures decreased with both 20 (HR $0.58,95 \%$ CI 0.38 to 0.89 ) and 40 (HR $0.63,95 \%$ CI 0.42 to $0.96) \mathrm{mg}$ of bazedoxifene per day compared to placebo. ${ }^{57}$ The reduction was in the same range as with raloxifene $60 \mathrm{mg}$ (HR $0.58,95 \%$ CI 0.38 to 0.89 ). ${ }^{57}$ There was no reduction in the risk of non-vertebral fractures. ${ }^{57}$

A subgroup of women with a priori high risk of fractures was identified post-hoc. This group had femoral neck T-score ( -3.0 or lower) and/or the presence of at least one moderate or severe vertebral fracture or multiple mild vertebral fractures at baseline, resultin in a subgroup of 1772 women. Restricting the analysis to a post-hoc analysis of these 1772 women with high risk of fractures showed a $50 \%$ reduction in the risk of non-vertebral fractures with the $20 \mathrm{mg}$ dose of bazedoxifene compared to placebo (HR $0.50,95 \%$ CI 0.28 to 0.90$).{ }^{57}$ In the $40 \mathrm{mg}$ bazedoxifene group no significant reduction in nonvertebral fractures were seen in this subgroup of women at high risk of fractures (HR $0.70,95 \%$ CI 0.40 to 1.20 ).${ }^{57}$ In the $20 \mathrm{mg}$ bazedoxifene group at high risk of fractures $(n=1772)$ the risk of non-vertebral fractures was borderline significantly lower than with raloxifene (HR $0.56,95 \%$ CI 0.31 to 1.01). Also in the $40 \mathrm{mg}$ bazedoxifene group a non-significant trend towards a decrease in non-vertebral fractures compared to raloxifene was seen ( $\mathrm{HR} 0.78,95 \%$ CI 0.45 to 1.35$).{ }^{57}$

At 3 years the absolute risk of morphometric fractures was 4.1 with placebo, $2.3 \%$ with $20 \mathrm{mg}$ of bazedoxifene, and $2.5 \%$ with $40 \mathrm{mg}$ bazedoxifene. ${ }^{57}$ This yields numbers needed to treat of 56 for $20 \mathrm{mg}$ of bazedoxifene and 63 for $40 \mathrm{mg}$ of bazedoxifene for morphometric vertebral fractures, ie, 56 and 63 women have to be treated for 3 years to prevent one morphometric vertebral fracture. ${ }^{57}$ For non-vertebral fractures the corresponding numbers needed to treat were 167 for 20 of bazedoxifene and 143 for $40 \mathrm{mg}$ of bazedoxifene $(6.3 \%$ cumulated risk of nonvertebral fractures after 3 years vs 5.7 and 5.6\% respectively). ${ }^{57}$ In the high risk group the number needed to treat was 24 and 38 respectively with 20 and $40 \mathrm{mg}$ of bazedoxifene..$^{57}$ The latter lower number reflects a 3-year cumulated risk of non-vertebral fractures of $9.1 \%$ in the placebo group vs $4.9 \%$ and $6.5 \%$ with 20 and $40 \mathrm{mg}$ of bazedoxifene, respectively, ie, a much higher absolute risk of fractures. ${ }^{57}$ This also reflects that it is much easier to obtain statistical significance with a high absolute fracture risk than with a low risk of fractures. ${ }^{57}$ When small differences in absolute risk are converted to compute the numbers needed to treat, seemingly large differences in number are not significant owing to wide confidence intervals because small differences may convert into large numbers.

Kanis et $\mathrm{al}^{58}$ re-analyzed the data from the study by Silverman et al. ${ }^{57}$ Kanis et al did a post-hoc analysis based on the 10-year modeled risk of major osteoporotic fractures using the FRAX algorithm as co-variate. At a modeled 10 -year risk of major osteoporotic fractures above $16 \%$, bazedoxifene was associated with a significant decrease in both morphometric vertebral and clinical fractures. ${ }^{58}$ At a 10 -year risk of morphometric vertebral of $22 \%$, the hazard ratio for morphometric vertebral fractures was $0.49,95 \%$ CI 0.31 to 0.79 for bazedoxifene vs placebo and for clincial fractures the hazard ratio was $0.68,95 \%$ CI 0.49 to $0.93 .{ }^{58}$

The patients in this trial were thus at significantly higher risk of fractures than the above mentioned trial with BMD as end-point. ${ }^{55}$ 


\section{Adverse effects}

In the study by Miller et al, ${ }^{55}$ deep venous thromboembolism was rare with bazedoxifene $(0 \%$ to $0.6 \%$ with various doses after 2 years) and in the same range as placebo $(0.3 \%)$. Leg cramps were in the same range as with raloxifene and as with placebo. ${ }^{55}$ Hot flushes were in the same range as raloxifene, but a little higher than with placebo. ${ }^{55}$ In the study by Silverman et $\mathrm{al}^{57}$ leg cramps $(10.9 \%$ to $11.7 \%$ with various doses after 3 years) and deep venous thromboembolism ( $0.4 \%$ to $0.5 \%$ with various doses after 3 years) were significantly more frequent with bazedoxifene than with placebo ( 8.2 for leg cramps and $0.2 \%$ for deep venous thromboembolism), while breast cyst/fibrocystic breast disease was significantly less frequent.

Extensive monitoring of has cardiovascular side effects been performed, and no difference between bazedoxifene and placebo were observed for myocardial infarction, strokes (ischemic or hemorraghic strokes), or retinal vein thrombosis. ${ }^{55,57}$ This is particularly interesting given the tissue-specific actions of the various estrogen receptors.

\section{Combinations of bazedoxifene and conjugated estrogens}

In general SERMs have been shown to have weaker action on BMD than conjugated estrogen or 17-beta-estradiol. ${ }^{59}$ This has led to examination of combinations of bazedoxifene and estrogen. However, at present no definite data on BMD in humans are available. In animals the combination of bazedoxifene and conjugated estrogen showed that with bazedoxifene $3 \mathrm{mg} / \mathrm{kg}$ an increase in bone density similar to that for conjugated estrogen 2.5 to $5 \mathrm{mg} / \mathrm{kg}$, but higher than that for 0.5 to $1 \mathrm{mg} / \mathrm{kg} .{ }^{60}$ The combination of bazedoxifene $3 \mathrm{mg} / \mathrm{kg}$ and conjugated estrogen in all doses showed an increase in bone density. ${ }^{60}$ However, the increase at the doses of $3 \mathrm{mg} / \mathrm{kg}$ of bazedoxifene and 2.5 to $5 \mathrm{mg} / \mathrm{kg}$ of conjugated estrogen was a little less than with conjugated estrogen alone, although the difference was not statistically significant. ${ }^{60}$ Bazedoxifene plus conjugated estrogen in animals seems to counter some of the detrimental effects seen in humans. ${ }^{53,54,60}$ However, more human data are needed.

\section{Other drugs against osteoporosis}

In accordance with the results for bazedoxifene, ${ }^{57}$ raloxifene has also been shown to reduce only vertebral but not nonvertebral fractures in the intention-to-treat analysis in randomized controlled trials. ${ }^{22-26}$ In contrast, the bisphosphonates alendronate, ${ }^{56,61}$ risedronate, ${ }^{62,63}$ and zoledronate ${ }^{64}$ have been shown to reduce both vertebral and non-vertebral fracture risk in randomized controlled trials. For the other bisphosphonates, etidronate, ${ }^{65}$ ibandronate, ${ }^{66}$ pamidronate,${ }^{67,68}$ and clodronate,${ }^{69}$ randomized controlled trials have demonstrated effect only on vertebral fractures. Strontium ranelate has demonstrated effects on vertebral ${ }^{70}$ and non-vertebral fractures. ${ }^{71}$ The parathyroid hormone teriparatide has been shown to reduce vertebral and non-vertebral fracture risk. ${ }^{72}$ However, for recombinant 1-84-PTH only a reduction in vertebral and not non-vertebral fractures has been demonstrated..$^{73,74}$

\section{Comments}

Bazedoxifene has shown effects on the risk of vertebral but not non-vertebral fracture risk in the intention-to-treat analysis in randomized controlled trials, in line with the results for raloxifene. ${ }^{57}$ In post-hoc analyses, high risk groups have shown a decrease in non-vertebral fracture risk. However, post-hoc subgroup analyses have been discredited in prior recommendations. ${ }^{75} \mathrm{It}$ is recommended that any subgroup analyses should be preplanned to avoid searching for significant results. ${ }^{75}$ Although subgroup analyses may help to generate hypotheses and explore data, they should be performed and interpreted with caution and should not be used as definite evidence for an effect. By analyzing data in subgroups randomization is usually discouraged, and the analyses are to be graded as cohort studies in terms of level of evidence unless the randomization is stratified on the subgroups.

At present the evidence supports an effect of bazodoxifene on vertebral fractures in postmenopausal women, whereas further studies are needed to establish if an effect on non-vertebral fractures is present in high risk subgroups. The effect of bazedoxifene on the skeleton is thus in line with the effect of raloxifene, and bazedoxifene may be used on the same indications as raloxifene. The value of bazedoxifene may lie in a different risk profile than raloxifene, especially in terms of uterine safety, and bazedoxifene may thus offer an alternative for prevention and treatment of osteoporosis in some groups of women.

\section{Disclosures}

The authors declare no conflicts of interest.

\section{References}

1. Bazedoxifene: bazedoxifene acetate, TSE 424, TSE-424, WAY 140424 Drugs RD. 2008;9:191-196.

2. Vogel V, Costantino J, Wickerham D, Cronin W, Cecchini R, Atkins J, et al. Effects of tamoxifen vs raloxifene on the risk of developing invasive breast cancer and other disease outcomes: the NSABP Study of Tamoxifen and Raloxifene (STAR) P-2 trial. JAMA. 2006;295:2727-2741.

3. Alexeeva L, Burkhardt P, Christiansen C, Cooper C, Delmas P, Johnell $\mathrm{O}$, et al. Assessment of fracture risk and its application to screening for postmenopausal osteoporosis: report of a WHO Study Group. WHO Technical Report Series 843, Geneva, 1994. 
4. Riggs BL, Melton LJ III, eds. Osteoporosis: Etiology, Diagnosis, and Management. Philadelphia: Lippincott-Raven Publishers; 1995.

5. Christiansen C, Christensen M, McNair P, Hagen C, Stocklund K, Transbøl I. Prevention of early bone postmenopausal loss: controlled 2-year study in 315 normal females. Eur J Clin Invest. 1980;10: 273-279.

6. Risks and benefits of estrogen plus progestin in healthy postmenopausal women: principal results from the Women's Health Initiative randomized controlled trial. JAMA. 2002;288:321-333.

7. Cauley J, Robbins J, Chen Z, Cummings S, Jackson R, LaCroix A, et al. Effects of estrogen plus progestin on risk of fracture and bone mineral density: The women's health initiative randomized trial. JAMA. 2003;290:1729-1738.

8. Anderson GL, Limacher M, Assaf AR; Women's Health Initiative Steering Committee. Effects of conjugated equine estrogen in postmenopausal women with hysterectomy: The Women's Health Initiative randomized controlled trial. JAMA. 2004;291:1701-1712.

9. Torgerson D, Bell-Syer S. Hormone replacement therapy and prevention of nonvertebral fractures. A meta-analysis of randomized trials. JAMA. 2001;285:2891-2897.

10. Torgerson D, Bell-Syer S. Hormone replacement therapy and prevention of vertebral fractures: a meta-analysis of randomised trials. $B M C$ Musculoskeletal Disorders. 2001;2:7-10.

11. Beresford SA, Weiss NS, Voigt LF, McKnight B. Risk of endometrial cancer in relation to use of oestrogen combined with cyclic progestagen therapy in postmenopausal women. Lancet. 1997;349:458-461.

12. Beral V, Banks E, Reeves G. Evidence from randomised trials on the long-term effects of hormone replacement therapy. Lancet. 2002;360:942-944.

13. Mosekilde L, Beck-Nielsen H, Sørensen O, Nielsen S, Charles P, Vestergaard $\mathrm{P}$, et al. Hormonal replacement therapy reduces forearm fracture incidence in recent postmenopausal women - results of the Danish Osteoporosis Prevention Study. Maturitas. 2000;36: 181-193.

14. Mosekilde L, Vestergaard P, Andresen J, Brixen K, Beck-Jensen J, Nielsen S, et al. Effects of 10 years of estradiol on fracture risk and other outcomes in early postmenopausal women - the Danish Osteoporosis Prevention Study. Calcif Tissue Int. 2004;74:S38-S38.

15. Couse JF, Lindzey J, Grandien K, Gustafsson JA, Korach KS. Tissue distribution and quantitative analysis of estrogen receptor-alpha (ERalpha) and estrogen receptor-beta (ERbeta) messenger ribonucleic acid in the wild-type and ERalpha-knockout mouse. Endocrinology. 1997; 138:4613-4621.

16. Fisher B, Costantino J, Redmond C, Fisher E, Wickerham D, Cronin W. Endometrial cancer in tamoxifen-treated breast cancer patients: findings from the National Surgical Adjuvant Breast and Bowel Project (NSABP) B-14. J Natl Cancer Inst. 1994;86:527-537.

17. Vestergaard P, Rejnmark L, Mosekilde L. Effect of tamoxifen and aromatase inhibitors on the risk of fractures in women with breast cancer. Calcif Tissue Int. 2008;82:334-340.

18. Love R, Maxess R, Barden H, Epstein S, Newcomb P, Jordan V, et al. Effects of tamoxifen on bone mineral density in postmenopausal women with breast cancer. $N$ Engl J Med. 1992;326:852-856.

19. Love R, Barden H, Mazess R, Epstein S, Chappell R. Effect of tamoxifen on lumbar spine bone mineral density in postmenopausal women after 5 years. Arch Intern Med. 1994;154:2585-2588.

20. Neal A, Evans K, Hoskin P. Does long-term administration of tamoxifen affect bone mineral density? Eur J Cancer. 1993;29A:1971-1973.

21. Delmas P, Bjarnason N, Mitlak B, Ravoux A, Shah A, Huster W, et al. Effects of raloxifene on bone mineral density, serum cholesterol concentrations, and uterine endometrium in postmenopausal women. N Engl J Med. 1997;337:1641-1647.

22. Delmas P, Ensrud K, Adachi J, Harper K, Sarkar S, Gennari C, et al. Efficacy of raloxifene on vertebral fracture risk reduction in postmenopausal women with osteoporosis: four-year results from a randomized clinical trial. J Clin Endocrinol Metab. 2002;87: $3609-3617$.
23. Ettinger B, Black D, Mitlak B, Knickerbocker R, Nickelsen T, Genant $\mathrm{H}$, et al. Reduction of vertebral fracture risk in postmenopausal women with osteoporosis treated with raloxifene: results from a 3-year randomized clinical trial. JAMA. 1999;282:637-645.

24. Maricic M, Adachi J, Sarkar S, Wu W, Wong M, Harper K. Early effects of raloxifene on clinical vertebral fractures at 12 months in postmenopausal women with osteoporosis. Arch Intern Med. 2002;162:1140-1143.

25. Seeman E, Crans G, Diez-Perez A, Pinette K, Delmas P. Anti-vertebral fracture efficacy of raloxifene: a meta-analysis. Osteoporos Int. 2006; 17:313-316.

26. Siris E, Harris S, Eastell R, Zanchetta J, Goemaere S, Diez-Perez A, et al. Skeletal effects of raloxifene after 8 years: results from the Continuing Outcomes Relevant to Evista (CORE) Study. J Bone Miner Res. 2005;20:1514-1524.

27. Cranney A, Tugwell P, Zytaruk N, Robinson V, Weaver B, Adachi J, et al. Meta-analysis of raloxifene for the prevention and treatment of postmenopausal osteoporosis. Endocr Rev. 2002;23:524-528.

28. Cummings S, Eckert S, Krueger K, Grady D, Powles T, Cauley J, et al. The effect of raloxifene on risk of breast cancer in postmenopausal women: results from the MORE randomized trial. Multiple Outcomes of Raloxifene Evaluation. JAMA. 1999;281:2189-2197.

29. Martino S, Cauley J, Barrett-Connor E, Powles T, Mershon J, Disch D, et al. Continuing outcomes relevant to Evista: breast cancer incidence in postmenopausal osteoporotic women in a randomized trial of raloxifene. J Natl Cancer Inst. 2004;96:1751-1761.

30. Barrett-Connor E, Mosca L, Collins P, Geiger M, Grady D, Kornitzer M, et al. Effects of raloxifene on cardiovascular events and breast cancer in postmenopausal women. $N$ Engl J Med. 2006;355:125-137.

31. Barrett-Connor E, Grady D, Sashegyi A, Anderson P, Cox D, Hoszowski K, et al. Raloxifene and cardiovascular events in osteoporotic postmenopausal women: four-year results from the MORE (Multiple Outcomes of Raloxifene Evaluation) randomized trial. JAMA. 2002;287:847-857.

32. http://www.emea.europa.eu/humandocs/PDFs/EPAR/conbriza/ H-913-PI-en.pdf.

33. Lasofoxifene: CP 336156, CP-336156. Drugs RD. 2005;6:56-60.

34. Ariazi E, Ariazi J, Cordera F, Jordan V. Estrogen receptors as therapeutic targets in breast cancer. Curr To pMed Chem. 2006;6:181-202.

35. Vestergaard P, Rejnmark L, Mosekilde L. Osteoporosis is markedly underdiagnosed - a nationwide study from Denmark. Osteoporosis Int. 2005; 16:134-141.

36. Marshall D, Johnell O, Wedel H. Meta-analysis of how well measures of bone mineral density predict occurrence of osteoporotic fractures. BMJ. 1996;312:1254-1259.

37. Kanis J, Johnell O, De Laet C, Johansson H, Oden A, Delmas P, et al. A meta-analysis of previous fracture and subsequent fracture risk. Bone. 2004;35:375-382.

38. Vestergaard P, Olsen M, Johnsen S, Rejnmark L, Sørensen H, Mosekilde L. Corticosteroid use and risk of hip fracture: a population-based case-control study in Denmark. J Intern Med. 2003;254:486-493.

39. Kanis J, Johansson H, Oden A, Johnell O, De Laet C, Melton III L, et al. A meta-analysis of prior corticosteroid use and fracture risk. J Bone Miner Res. 2004;19:893-899.

40. Vestergaard P, Mosekilde L. Fracture risk associated with smoking a meta-analysis. J Intern Med. 2003;254:572-583.

41. Kanis J, Johnell O, Oden A, Johansson H, De Laet C, Eisman J, et al. Smoking and fracture risk: a meta-analysis. Osteoporosis Int. 2005;16:155-162.

42. Kanis J, Johansson H, Johnell O, Oden A, De Laet C, Eisman J, et al. Alcohol intake as a risk factor for fracture. Osteoporosis Int. 2005; 16:737-742

43. De Laet C, Kanis J, Oden A, Johanson H, Johnell O, Delmas P, et al. Body mass index as a predictor of fracture risk: A meta-analysis. Osteoporosis Int. 2005;16:1330-1338.

44. Cummings S, Nevitt M, Browner W, Stone K, Fox K, Ensrud K, et al. Risk factors for hip fracture in white women. Study of Osteoporotic Fractures Research Group. N Engl J Med. 1995;332:767-773. 
45. Vestergaard P, Rejnmark L, Mosekilde L. Fracture risk associated with use of morphine and opiates. J Intern Med. 2006;260:76-87.

46. Vestergaard P. Effect of selective serotonin reuptake inhibitors on the risk of fracture. Aging Health. 2007;3:349-350.

47. Vestergaard P, Rejnmark L, Mosekilde L. Anxiolytics, sedatives, antidepressants, neuroleptics and the risk of fracture. Osteoporosis Int. 2006;17:807-816.

48. Kanis J, Johnell O, Oden A, Johansson H, McCloskey E. FRAX and the assessment of fracture probability in men and women from the UK. Osteoporosis Int. 2008;19:385-397.

49. Vestergaard P. Anti-resorptive therapy for the prevention of postmenopausal osteoporosis: when should treatment begin? Treat Endocrinol. 2005;4:263-277.

50. Chandrasekaran A, McKeand W, Sullivan P, DeMaio W, Stoltz R, Scatina J. Metabolic disposition of [14C]bazedoxifene in healthy postmenopausal women. Drug Metab Dispos. 2009;37:1219-1225.

51. Crabtree J, Peano B, Zhang X, Komm B, Winneker R, Harris H. Activity of three selective estrogen receptor modulators on hormone-dependent responses in the mouse uterus and mammary gland. MolCell Endocrinol. 2008;287:40-46.

52. Komm B, Kharode Y, Bodine P, Harris H, Miller C, Lyttle C. Bazedoxifene acetate: a selective estrogen receptor modulator with improved selectivity. Endocrinology. 2005;146:3999-4008.

53. Peano B, Crabtree J, Komm B, Winneker R, Harris H. Effects of various selective estrogen receptor modulators with or without conjugated estrogens on mouse mammary gland. Endocrinology. 2009;150: 1897-1903.

54. Ronkin S, Northington R, Baracat E, Nunes M, Archer D, Constantine G, et al. Endometrial effects of bazedoxifene acetate, a novel selective estrogen receptor modulator, in postmenopausal women. Obstet Gynecol. 2005;105:1397-1404.

55. Miller P, Chines A, Christiansen C, Hoeck H, Kendler D, Lewiecki E, et al. Effects of bazedoxifene on BMD and bone turnover in postmenopausal women: 2-yr results of a randomized, double-blind, placeboand active-controlled study. J Bone Miner Res. 2008;23:525-535.

56. Black D, Cummings S, Karpf D, Cauley J, Thompson D, Nevitt M, et al. Randomised trial of the effect of alendronate on risk of fracture in women with existing vertebral fractures. Lancet. 1996;348 $1535-1541$.

57. Silverman S, Christiansen C, Genant H, Vukicevic S, Zanchetta J, de Villiers T, et al. Efficacy of bazedoxifene in reducing new vertebral fracture risk in postmenopausal women with osteoporosis: results from a 3-year, randomized, placebo-, and active-controlled clinical trial. J Bone Miner Res. 2008;23:1923-1934.

58. Kanis J, Johansson H, Oden A, McCloskey E. Bazedoxifene reduces vertebral and clinical fractures in postmenopausal women at high risk assessed with FRAX. Bone. 2009;44:1049-1054.

59. Dane C, Dane B, Cetin A, Erginbas M. Comparison of the effects of raloxifene and low-dose hormone replacement therapy on bone mineral density and bone turnover in the treatment of postmenopausal osteoporosis. Gynecol Endocrinol. 2007;23:398-403.

60. Kharode Y, Bodine P, Miller C, Lyttle C, Komm B. The pairing of a selective estrogen receptor modulator, bazedoxifene, with conjugated estrogens as a new paradigm for the treatment of menopausal symptoms and osteoporosis prevention. Endocrinology. 2008;149:6084-6091.
61. Cranney A, Wells G, Willan A, Griffith L, Zytaruk N, Robinson V, et al. Meta-Analysis of Alendronate for the Treatment of Postmenopausal Women. Endocr Rev. 2002;23:508-516.

62. Cranney A, Tugwell P, Adachi J, Weaver B, Zytaruk N, Papaioannou A, et al. Meta-analysis of risedronate for the treatment of postmenopausal osteoporosis. Endocr Rev. 2002;23:517-523.

63. McClung M, Geusens P, Miller P, Zippel H, Bensen W, Roux C, et al. Effect of risedronate on the risk of hip fracture in elderly women. Hip Intervention Program Study Group. N Engl J Med. 2001;344: 333-340.

64. Black D, Delmas P, Eastell R, Reid I, Boonen S, Cauley J, et al. Onceyearly zoledronic acid for treatment of postmenopausal osteoporosis N Engl J Med. 2007;356:1809-1822.

65. Cranney A, Guyatt G, Krolicki N, Welch V, Griffith L, Adachi J, et al. A meta-analysis of etidronate for the treatment of postmenopausal osteoporosis. Osteoporosis Int. 2001;12:140-151.

66. Chesnut III C, Skag A, Christiansen C, Recker R, Stakkestad J, Hoiseth A, et al. Effects of oral ibandronate administered daily or intermittently on fracture risk in postmenopausal osteoporosis. $J$ Bone Miner Res. 2004;19:1241-1249.

67. Brumsen C, Papapoulos S, Lips P, Geelhoed-Duijvestijn P, Hamdy N, Landman J, et al. Daily oral pamidronate in women and men with osteoporosis: a 3-year randomized placebo-controlled clinical trial with a 2-year open extension. J Bone Miner Res. 2002;17:1057-1064.

68. Reid I, Wattie D, Evans M, Gamble G, Stapleton J, Cornish J. Continuous therapy with pamidronate, a potent bisphosphonate, in postmenopausal osteoporosis. J Clin Endocrinol Metab. 1994;79:1595-1599.

69. McCloskey E, Selby P, Davies M, Robinson J, Francis R, Adams J, et al. Clodronate reduces vertebral fracture risk in women with postmenopausal or secondary osteoporosis: results of a double-blind, placebocontrolled 3-year study. J Bone Miner Res. 2004;19:728-736.

70. Meunier P, Roux C, Seeman E, Ortolani S, Badurski J, Spector T, et al. The effects of strontium ranelate on the risk of vertebral fracture in women with postmenopausal osteoporosis. $N$ Engl $\mathrm{J} \mathrm{Med}$. 2004;350:459-468.

71. Reginster J, Seeman E, de Vernejoul M, Adami S, Compston J, Phenekos C, et al. Strontium ranelate reduces the risk of nonvertebral fractures in postmenopausal women with osteoporosis: Treatment of Peripheral Osteoporosis (TROPOS) study. J Clin Endocrinol Metab. 2005;90:2816-2822.

72. Neer R, Arnaud C, Zanchetta J, Prince R, Gaich G, Reginster J, et al. Effect of parathyroid hormone (1-34) on fractures and bone mineral density in postmenopausal women with osteoporosis. $N$ Engl $J$ Med. 2001;344:1434-1441.

73. Greenspan S, Bone H, Ettinger M, Hanley D, Lindsay R, Zanchetta J, et al. Effect of recombinant human parathyroid hormone (1-84) on vertebral fracture and bone mineral density in postmenopausal women with osteoporosis: a randomized trial. Ann Intern Med. 2007;146: 326-339.

74. Lindsay R, Nieves J, Formica C, Henneman E, Woelfert L, Shen V, et al. Randomised controlled study of effect of parathyroid hormone on vertebral-bone mass and fracture incidence among postmenopausal women on oestrogen with osteoporosis. Lancet. 1997;350:550-555.

75. Rothwell P. Treating Individuals 2: Subgroup analysis in randomised controlled trials: importance, indications, and interpretation. Lancet. 2005;365:176-186.
International Journal of Women's Health

\section{Publish your work in this journal}

The International Journal of Women's Health is an international, peerreviewed open-access journal publishing original research, reports, reviews and commentaries on all aspects of women's healthcare including gynaecology, obstetrics, and breast cancer. Subject areas include: Chronic conditions (migraine headaches, arthritis, osteoporosis);

\section{Dovepress}

Endocrine and autoimmune syndromes; Sexual and reproductive health; Psychological and psychosocial conditions. The manuscript management system is completely online and includes a very quick and fair peer-review system. Visit http://www.dovepress.com/ testimonials.php to read real quotes from published authors. 